\title{
An Efficient Method for Isolation of Plasmid DNA for Transfection of Mammalian Cell Cultures
}

\author{
Daniel V. Kachkin ${ }^{1,2, *,+} \mathbb{0}$, Julia I. Khorolskaya ${ }^{3,+}$, Julia S. Ivanova ${ }^{3}$ \\ and Aleksandr A. Rubel 1,2,*iD \\ 1 Laboratory of Amyloid Biology, St. Petersburg State University, 199034 St. Petersburg, Russia \\ 2 Department of Genetics and Biotechnology, St. Petersburg State University, 199034 St. Petersburg, Russia \\ 3 Institute of Cytology Russian Academy of Science, 194064 St. Petersburg, Russia; \\ khorolskaya@incras.ru (J.I.K.); ju.s.ivanova@yandex.ru (J.S.I.) \\ * Correspondence: pspdaniel@mail.ru (D.V.K.); arubel@mail.ru (A.A.R.); \\ Tel.: +7-9111333968 (D.V.K.); +7-9111333968 (A.A.R.) \\ + These authors contributed equally to this work.
}

Received: 1 September 2020; Accepted: 1 October 2020; Published: 14 October 2020

check for updates

\begin{abstract}
In this article, we present several protocols that describe the steps from cloning and obtaining a large amount of pure plasmid DNA to generation of lentiviruses based on these constructs. The protocols have been worked out on human cell culture HEK293T but can be adapted for other cell cultures. This protocol was designed to be simple to execute and cheap since it requires only materials and consumables widely available in molecular laboratories, such as salts, alcohols, etc., and no complicated laboratory equipment. These protocols are highly effective and can be performed in any standard molecular biology laboratory.
\end{abstract}

Keywords: plasmid; mammalian cell transfection; lentiviral transduction; lentivirus; HEK293T; E. coli

\section{Introduction}

Transfection is a procedure that introduces DNA and RNA into eukaryotic cells to produce genetically modified cells. Transfection is a powerful analytical tool for studying gene function and their regulation by enhancing or inhibiting specific gene expression in cells. It is also important for studying proteins or producing recombinant proteins in mammalian cells [1]. Transfection can be used in gene therapy, for production of recombinant proteins for therapeutic purposes, small interference RNA knockdown procedures [2] and is an essential step for lentivirus production [3].

There are various approaches for mammalian cell transfection. However, one of the key factors for successful transfection remains the quality and the quantity of the transfected material (DNA, RNA). To transfect human cells, a researcher needs a large amount of high-quality DNA. DNA midi- or maxiprep kits are often expensive and the amount of DNA isolated with their help is often insufficient.

In this study, we developed a new protocol suitable to achieve a high yield of plasmid DNA of high purity, acceptable for the transfection of mammalian cell cultures. Our method can also significantly reduce the cost of DNA isolation, since it provides a high yield of extracted plasmid without an implementation of commercial kits.

For this method, we used the E. coli bacterial strain STBL3 (ThermoFisher Scientific, Walthon, MA, USA). This strain was designed especially for cloning the direct repeats found in lentiviral expression vectors and it gives a higher yield of extracted DNA. However, the introduced protocol is probably compatible with any E. coli strain used for the cloning.

The DNA purity is sufficient for basic transfection methods using cationic polymers, such as PEI (polyethylenimine) or TurboFect (ThermoFisher, Walthon, MA, USA). Transfection using PEI has several advantages, like its cheapness and suitability for various cell cultures [4]. 
Lentiviral technology came to widespread use in molecular and cell biology for stable gene expression, gene silencing, generating transgene animals, induction of pluripotent stem cells, stem cell modification and lineage tracking, immunization and in vivo imaging [5]. Lentiviral technology is based on the co-transfection of human cell line HEK293T with packaging, envelope and transfer plasmids (containing the gene of interest). This is resulted in the assembly of the lentivirus, which, upon transduction, became a powerful tool for the expression of exogenous genes into various types of cells both in vitro and in vivo. Today, this method is the most effective way to obtain stable cell lines producing the studied genetic products [6].

These protocols can be easily reproduced in almost any lab, they have a good efficiency and may be necessary for the wide range of studies in cell and molecular biology.

In this article, we offer well-reproducible, high-performance protocols that are guided and adapted to work with mammalian cell cultures. This protocol of plasmid DNA extraction is also applicable to other techniques where a large amount of plasmid DNA is required.

\section{Experimental Design}

In this article, we propose an optimized protocol for the isolation of plasmid DNA (Figure 1) from bacterial cultures without the use of commercial kits for its subsequent application in genetic modifications of mammalian cell cultures. The advantages of this method are as follows: a high efficiency (concentration of plasmid DNA at the output is $3-8 \mathrm{mg} / \mathrm{mL}$ ), availability, sufficient purity of the obtained material, as well as cheapness along with relatively low time costs. In addition, the protocol contains a description of the methods for efficient transfection and assembly of lentiviral particles based on the obtained plasmid DNA, which have been successfully tested for immortalized and primary mammalian cell cultures.

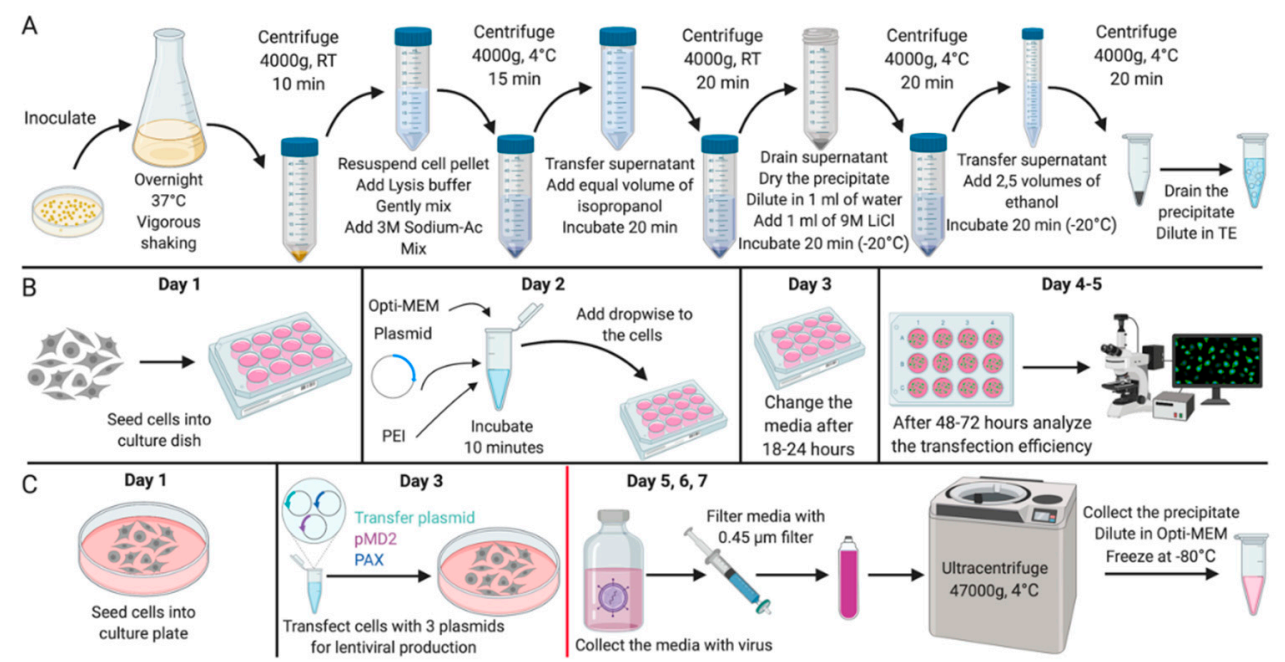

Figure 1. Experimental design. Scheme of (A) the experiment for the isolation of plasmid DNA; (B) the experiment for the mammalian cells transfection; (C) the experiment for the lentiviral vector production. All stages after the change of media on Day 4 should be carried out with the proper biosafety containment recommended for research with lentiviral vectors. Created with BioRender.com.

We recommend using plasmids containing fluorescent labels, as this will provide the best control over the experiment, calculation of transfection/transduction efficiency and viral assembly.

The plasmids obtained for the study were transformed into E. coli according to the Inoue standard protocol [7]. We used the plasmids pLenti-CMV-EGFP Hygro (656-4) [8], pMD2 (gift from Didier Trono (Addgene plasmid \# 12259)) and PAX2 (gift from Didier Trono (Addgene plasmid \# 12260)). The protocol is based on the Birnboim and Doly DNA extraction protocols with modifications $[9,10]$. 
This protocol lists the plasmids and strain used in this study, but the DNA extraction protocol is suitable for all strains and plasmids. It is suitable for all researchers working with cell cultures due to its simplicity and it does not require complicated equipment or expensive reagents.

\subsection{Materials}

- Tris base (ThermoFisher Scientific, USA; Cat. no.:15504020);

- $\quad$ EDTA Disodium Salt 2-hydrate (PanReac AppliChem, USA; Cat. no.:141669);

- Yeast Extract w/o salts (Helicon, Russia; Cat. no.: H-0601MG-0.5);

- D-Glucose monohydrate (Helicon, Russia; Cat. no.: Roquette-361103-0.5);

- $\quad$ Tryptone (VWR Life Science AMRESCO, USA; Cat. no.: 97063-388);

- $\quad$ Agar, European type (PanReac AppliChem, USA; Cat. no.: 402302.1210-1);

- Sodium Cloride (Helicon, Russia; Cat. no.: H-1418-1.0);

- Lithium Chloride (Sigma-Aldrich, USA; Cat. no: L4408);

- Sodium Acetate (PanReac AppliChem, USA; Cat. no.: 131633);

- $\quad$ Sodium hydroxide (PanReac AppliChem, USA; Cat. no.: 211687);

- Sodium Dodecyl Sulfate (PanReac AppliChem, USA; Cat. no.: 142363);

- $\quad$ RNAse A (Sigma-Aldrich, USA; Cat. no: R6148);

- Antibiotic for plasmid selection (we used Ampicillin (Sigma-Aldrich, USA; Cat. no.: 10835242001));

- Ethanol;

- Isopropanol;

- Dulbecco's Modified Eagle Medium (DMEM; Gibco, USA; Cat. no.: 41965039);

- Opti-MEM Reduced-Serum Medium (Gibco, USA; Cat. no.: 51985026);

- Defined Fetal Bovine Serum, (FBS; HyClone, USA; Cat. no.: SH30070.03);

- L-glutamine (Gibco, USA; Cat. no.:25030024);

- Penicillin-streptomycin (Gibco, USA; Cat. no.:15070063);

- Polyethylenimine (PEI) HCl MAX, MW 40000 (Polysciences, USA; Cat. no.: 24765-1);

- Hexadimethrine bromide (Polybrene) (Sigma-Aldrich, USA; Cat. no.: 107689);

- Bacterial strain STBL3 (ThermoFisher Scientific, USA);

- Human cell line HEK293T (Cells were obtained from the Russian Cell Culture Collection (Institute of Cytology, St. Petersburg, Russia));

- $\quad$ pMD2-envelope plasmid (gift from Didier Trono, addgene plasmid \# 12259);

- PAX2-packaging plasmid (gift from Didier Trono, addgene plasmid \# 12260);

- $\quad$ LLenti-CMV-GFP Hygro (656-4)—transfer lentiviral plasmid [8].

\subsection{Equipment}

- Tissue culture-treated plates (TPP Techno Plastic Products AG Schaffhausen, Trasadingen, Switzerland);

- $15 \mathrm{~mL}$ Falcon Conical Centrifuge Tubes (Corning, Corning, USA; Cat. no.: 352095);

- $50 \mathrm{~mL}$ Conical Centrifuge Tubes (Corning, Corning, NY, USA; Cat. no: 352070);

- $\quad$ Syringe 0.45- $\mu \mathrm{m}$ filter (Jet Bio-Filtration, Guangzhou, China; Cat. no.: FPE404030);

- Polycarbonate centrifuge bottles (Beckman Coulter, Brea, CA, USA; Cat. no: 363420);

- New Brunswick Galaxy 170R $\mathrm{CO}_{2}$ incubator (Eppendorf, Hamburg, Germany);

- Class II, Type A2 Biological Safety Cabinets (Lamsystems, Miass, Russia);

- ZOE Fluorescent cell imager (Bio-Rad, Hercules, CA, USA);

- Inverted microscope Eclipse TS100 (Nikon, Tokyo, Japan);

- Vortex Genius 3 (IKA, Staufen, Germany);

- Shaker incubator (Biosan, Riga, Latvia);

- Petri dishes for microbiology (Helicon, Moscow, Russia); 
- Centrifuge with cooling Eppendorf 5810 R (Eppendorf, Hamburg, Germany);

- Avanti J-E Centrifuge (Beckman Coulter, Brea, CA, USA; Cat. no: 369005);

- CytoFLEX Flow Cytometer (Beckman Coulter, Brea, CA, USA);

- Spectrophotometer Nanodrop TB-1000, ThermoFisher Scientific, Walthon, MA, USA).

\section{Procedure}

\subsection{Plasmid DNA Isolation from E. coli Bacteria-Time for Completion: 16-18 h}

1. Inoculate a single colony transformed with the desired plasmid from the plate with LB (+ antibiotic for selection) into $50 \mathrm{~mL}$ of liquid medium (LB or TBR) with the appropriate antibiotic added. Note: The flask for growing the bacteria should be at least $4-5$ times larger than the volume of the medium in which the bacteria grow. This is necessary for a better aeration of the culture.

2. Grow the cells with vigorous shaking overnight at $37^{\circ} \mathrm{C}$.

3. Transfer the cells to centrifuge tubes $(\mathrm{V}=50 \mathrm{~mL})$ and centrifuge at $4000 \times \mathrm{g}$ for $10 \mathrm{~min}$ at room temperature.

4. Carefully drain the supernatant and resuspend the cell pellet in $5 \mathrm{~mL}$ of sterile water or TEG with the addition of RNAse (3-5 $\mu \mathrm{L} / \mathrm{mL}$ ). Add TEG (Tris-EDTA-Glucose buffer) at sterile conditions, to avoid contamination.

5. Add $10 \mathrm{~mL}$ of a lysis solution $(0.2 \mathrm{~N} \mathrm{NaOH} ; 1 \% \mathrm{SDS})$ to the cell suspension. Gently mix by inverting the tube until all cells are lysed. It is important to mix the tube gently by inverting to avoid contamination by genomic DNA.

6. Add $7.5 \mathrm{~mL}$ of $3 \mathrm{M}$ sodium acetate $(\mathrm{pH}=5.0)$ and mix thoroughly. Incubate the sample for $10 \mathrm{~min}$ at $4{ }^{\circ} \mathrm{C}$.

Note: If the precipitate does not settle well or flocs remain in the solution after the centrifugation, then the volume of the sodium acetate solution may be increased up to $10 \mathrm{~mL}$ or its $\mathrm{pH}$ is brought to 4.8 .

7. Centrifuge the sample for $15 \mathrm{~min}$ at $4000 \times g$ at $4{ }^{\circ} \mathrm{C}$.

8. Transfer the supernatant that contains the plasmid DNA to a new tube and add an equal volume of isopropanol. Thoroughly mix and incubate the sample for $15 \mathrm{~min}$ at room temperature. It is important to use high quality isopropanol as this directly affects the purity of the DNA.

9. Centrifuge for $20 \mathrm{~min}$ at $4000 \times g$ at room temperature.

10. Drain the supernatant and dry the precipitate. Dissolve the precipitate in $1 \mathrm{~mL}$ of sterile water.

11. Add $1 \mathrm{~mL}$ of $9 \mathrm{M} \mathrm{LiCl}$ to the sample, mix thoroughly and incubate $20 \mathrm{~min}$ at $-20^{\circ} \mathrm{C}$.

12. Centrifuge for $20 \mathrm{~min}$ at $4000 \times g$ at $-4{ }^{\circ} \mathrm{C}$.

13. Carefully transfer the supernatant to a new centrifuge tube $(\mathrm{V}=15 \mathrm{~mL})$. Discard the precipitate (it contains RNA and protein residues).

14. Add $5 \mathrm{~mL}$ of $96 \%$ ethanol to the supernatant. Vortex thoroughly.

15. Incubate for $1 \mathrm{~h}$ at $-20^{\circ} \mathrm{C}$.

(1) PAUSE STEP It is possible to pause the protocol here and leave samples at $-20^{\circ} \mathrm{C}$ overnight.

16. Centrifuge at $4000 \times g$ for $20 \mathrm{~min}$ at $4{ }^{\circ} \mathrm{C}$.

17. Discard the supernatant and thoroughly dry the precipitate.

18. Dissolve the plasmid DNA in $500 \mu \mathrm{L}$ of sterile water or TE buffer.

\subsection{Transfection of Human Cell Culture HEK293T Using PEI-Time for Completion: 3-5 Days}

1. One day before the transfection, seed HEK293T cells into a multi-well culture plate or a tissue culture dish with respect to the required number of cells per $1 \mathrm{~cm}^{2}$ (the approximate number of cells for different culture dishes is shown in Table 1). Cultivate the cells overnight in DMEM supplemented with $10 \%$ FBS, 1\% L-glutamine, and 1\% penicillin/streptomycin. 
A CRITICAL STEP It is crucial to check the cells for mycoplasma contamination; the presence of mycoplasma may significantly reduce the efficiency of the transfection or transduction.

2. Next day right before transfection prepare the DNA and PEI solution (transfection mix). The volume of transfection mix is $10 \%$ of the total volume of the culture medium (recommended by the manufacturer of culture dishes). Add the required amount of plasmid DNA (see Table 1) to the Opti-MEM and mix well on a vortex. Then, dropwise add PEI $(1 \mathrm{mg} / \mathrm{mL})$ to the DNA solution while vortexing.

Note: We recommend using plasmid DNA in a final concentration $1-2 \mathrm{mg} / \mathrm{mL}$. The amount of PEI may vary according to the amount of DNA. Avoid using concentrations higher than $5 \mu \mathrm{L} / \mathrm{mL}$ due to its high toxicity.

3. Incubate the transfection mix at room temperature for 10-15 $\mathrm{min}$.

4. Remove the medium from the cells and add the required amount of fresh DMEM supplemented with 10\% FBS, $1 \%$ L-glutamine, and $1 \%$ penicillin/streptomycin.

Note: The presence/absence of an antibiotic in the medium does not affect the efficiency of transfection. It is possible to use Opti-MEM instead of DMEM.

5. Add the transfection mix dropwise to the cells with a fresh culture medium and mix by gently swirling the culture dish.

6. Incubate the cells with the transfection mix in a tissue culture incubator at $37^{\circ} \mathrm{C}, 5 \% \mathrm{CO}_{2}$ for 18-24 h.

7. After the incubation, aspirate the medium with the transfection mix from the cells and add the required amount of DMEM supplemented with 10\% FBS, 1\% L-glutamine, and 1\% penicillin/streptomycin.

8. After $48-72 \mathrm{~h}$ of transfection, the effectiveness of the transfection can be evaluated. Note: For plasmids with fluorescent protein the effectiveness of the transfection can be evaluated by flow cytometry or fluorescent microscope. For other proteins use antibody or other staining.

Table 1. Approximate numbers of cells and reagents for HEK293T transfection.

\begin{tabular}{|c|c|c|c|c|c|}
\hline Tissue Culture Plate & $\begin{array}{l}\text { Number of Cells } \\
\text { per Well to Seed }\end{array}$ & $\begin{array}{l}\text { Final Medium } \\
\text { Volume (mL) }\end{array}$ & $\begin{array}{c}\text { Volume of the } \\
\text { Transfection Mix }(\mu \mathrm{L})\end{array}$ & $\begin{array}{l}\text { Amount of } \\
\text { DNA }(\mu g)\end{array}$ & $\begin{array}{c}\text { Amount of } \\
\text { PEI }(\mu \mathrm{L})\end{array}$ \\
\hline 48-well plate & 40,000 & 0.5 & 50 & 0.5 & 2.5 \\
\hline 12-well plate & 150,000 & 2 & 200 & 2 & 10 \\
\hline 6-well plate & 300,000 & 3 & 300 & 3 & 15 \\
\hline $60 \mathrm{~mm}$ culture dish & $1,000,000$ & 5 & 500 & 5 & 25 \\
\hline
\end{tabular}

\subsection{Lentiviral Vector Production-Time for Completion: 5-7 Days}

\subsubsection{Preparing Cells and Transfection}

1. Seed $1 \times 10^{6}$ HEK293T cells into a $100 \mathrm{~mm}$ culture plate three days before the planned transfection with lentiviral vector plasmids. On the day of transfection, cells should cover about $70 \%$ of the plate surface.

Note: Take four $100 \mathrm{~mm}$ culture plates for production of a sufficient amount of vector for further research. For small-scale purposes, one well of a 6-well plate may be enough.

OPTIONAL STEP We recommend to seed cells on Friday and make the transfection on Monday after the weekend so the whole process will be ended at the end of the working week.

OPTIONAL STEP We recommend to coat the surface of culture plates with gelatin (ATCC, USA) or collagen (Sigma-Aldrich, USA) for better adhesion of cells during experiments.

2. Transfect cells with three plasmids necessary for the virus production: pLenti-CMV-GFP Hygro (656-4) [8], PAX2 and pMD2. Right before transfection, prepare the DNA and PEI solutions. The volume of transfection mix is $10 \%$ of the total volume of the culture medium. Add the 
required amount of plasmid DNA (see Table 2) to the Opti-MEM and mix well on a vortex. Then, dropwise add PEI $(1 \mathrm{mg} / \mathrm{mL})$ to the DNA solution while vortexing.

Table 2. Approximate number of cells and reagents for virus production in HEK293T.

\begin{tabular}{cccccccc}
\hline Tissue Culture Plate & $\begin{array}{c}\text { Number of Cells to } \\
\text { Seed Three Days } \\
\text { before Transfection }\end{array}$ & $\begin{array}{c}\text { Final } \\
\text { Medium } \\
\text { Volume }(\mathbf{m L})\end{array}$ & $\begin{array}{c}\text { Volume of } \\
\text { Transfection } \\
\text { Mix }(\mu \mathrm{L})\end{array}$ & $\begin{array}{c}\text { Amount of } \\
\text { Vector } \\
\text { DNA }(\mu \mathrm{g})\end{array}$ & $\begin{array}{c}\text { Amount of } \\
\text { PAX } \\
\text { Plasmid }(\mu \mathrm{g})\end{array}$ & $\begin{array}{c}\text { Amount of } \\
\text { pMD2 } \\
\text { Plasmid }(\mu \mathrm{\mu g})\end{array}$ & $\begin{array}{c}\text { Amount of } \\
\text { PEI }(\mu \mathrm{L})\end{array}$ \\
\hline 6-well plate & 100,000 & 3 & 300 & 3.5 & 2.5 & 1.3 & 15 \\
60 mm plate & 300,000 & 6 & 600 & 6.5 & 5 & 2.5 & 40 \\
100 mm culture dish & $1,000,000$ & 10 & 1000 & 11 & 8 & 50 \\
\hline
\end{tabular}

3. Incubate the transfection mix at room temperature for $10-15 \mathrm{~min}$.

4. Change the media containing the transfection mix to fresh DMEM supplemented with $10 \%$ FBS, $1 \%$ L-glutamine, and $1 \%$ penicillin/streptomycin.

5. Add the transfection mix dropwise to the cells with a fresh culture medium and mix by gently swirling the culture dish.

6. Incubate the cells with the transfection mix in a tissue culture incubator at $37^{\circ} \mathrm{C}, 5 \% \mathrm{CO}_{2}$ for 18-24 h.

7. The next day after transfection, change the medium to fresh DMEM supplemented with $10 \% \mathrm{FBS}$, $1 \%$ L-glutamine, and $1 \%$ penicillin/streptomycin.

A CRITICAL STEP This and all following steps must be done with the proper biosafety containment recommended for research with lentiviral vectors [11].

\subsubsection{Harvesting the Lentiviral Vectors}

8. The next three days, collect daily the medium containing the virus in sterile $50-\mathrm{mL}$ centrifuge tubes. Store the medium at $+4{ }^{\circ} \mathrm{C}$ for up to one week.

9. On the fifth day after transfection, the collected medium must be filtered with a filter with a $0.45 \mu \mathrm{m}$ filter to get rid of cell debris in the medium.

OPTIONAL STEP For an easier filtration, it is possible to preliminarily centrifuge the collected medium ( 3 min at $500 \times g)$ to precipitate the main cell debris.

\subsubsection{Ultracentrifugation}

10. Transfer the filtered virus-containing medium to sterile polycarbonate centrifuge bottles suitable for ultracentrifugation and balance them carefully using suitable weights (to 3 decimal points).

$\triangle$ CRITICAL STEP the $50 \mathrm{~mL}$ centrifuge tubes must be strong enough to withstand a centrifugation speed of $50,000 \times g$.

11. Centrifuge the tubes for $2 \mathrm{~h}$ at $47,000 \times g$, at $+4{ }^{\circ} \mathrm{C}$. Note: After the centrifugation, at the bottom of the tube will be a barely noticeable whitish precipitate.

12. Take away the supernatant without touching the precipitate.

13. Thoroughly dissolve the precipitate in $150 \mu \mathrm{L}$ of Opti-MEM per $50 \mathrm{~mL}$ of harvested vectorcontaining medium by pipetting.

14. Leave them for $1 \mathrm{~h}$ at room temperature for better dissolution.

15. Centrifuge samples at low speed $(2000 \times g, 3 \mathrm{~min})$ to collect the media with the virus particles.

16. Aliquot samples into $20-50 \mu \mathrm{L}$ portions and freeze them at $-80^{\circ} \mathrm{C}$. In this state, the samples can be stored for a very long time.

A CRITICAL STEP We strongly recommend neither to repeat the freezing/thawing cycles for the virus nor to store it for a long time at $+4{ }^{\circ} \mathrm{C}$ and at room temperature, since its transduction efficiency can be significantly reduced. 


\subsubsection{Viral Titer Calculation}

17. Seed $5 \times 10^{4}$ HEK293T cells into a 24-well plate the day before transduction. Cultivate the cells overnight in DMEM supplemented with 10\% FBS, $1 \%$ L-glutamine, and 1\% penicillin/streptomycin.

18. The next day, prepare the 10-fold serial dilution of your lentivirus in $500 \mu \mathrm{L}$ of Opti-MEM. OPTIONAL STEP To increase the efficiency of the transduction, use hexadimethrine bromide (polybrene) (Sigma-Aldrich, USA) in concentration $5 \mu \mathrm{g} / \mathrm{mL}$. This step is essential for the primary lines.

19. Change the culture medium in the culture plate to the Opti-MEM medium with different dilutions of the virus (see Point 18) to infect the cells.

20. Incubate the cells in a tissue culture incubator at $37^{\circ} \mathrm{C}, 5 \% \mathrm{CO}_{2}$ for $18-24 \mathrm{~h}$.

21. The next day after transduction, change the medium to fresh DMEM supplemented with $10 \%$ FBS, $1 \%$ L-glutamine, and $1 \%$ penicillin/streptomycin.

22. Two days after transduction, perform a flow cytometry analysis to count the percentage of the infected cells per well. To detect the infected cells, use the fluorescence signal value for viruses containing a fluorescent protein or antibody/other staining for non-fluorescent ones.

23. Choose the well in which the percentage of infected cells do not exceed $20 \%$ and calculate the viral titer using the following equation: $T U / m L=(P \times N \times D) / V$, where TU/mL is a number of viral particles in $1 \mathrm{~mL}$ of viral solution; $\mathrm{P}$-percentage of infected cells $(0.01-0.2)$; $\mathrm{N}$-the number of cells in the well (at the time of seeding); $\mathrm{D}$ - the dilution fold of the added vector; and $\mathrm{V}$ - the volume $(\mathrm{mL})$ of the added vector.

\section{Expected Results}

During the approbation of the protocol for the isolation of plasmid DNA, we received on average of $5.6 \pm 2.1 \mu \mathrm{g} / \mu \mathrm{L}$ (which is about $56 \mu \mathrm{g}$ of DNA per $1 \mathrm{~mL}$ of overnight culture). We obtained such amounts of plasmid DNA using the bacterial strain STBL3.

The purity of the plasmids and the concentration was evaluated using the spectrophotometer NanoDrop (ND-1000). This is a quick method for estimating the amount of extracted DNA, as well as the relative amount of RNA and protein in a sample.

The ratio of absorbance at $260 \mathrm{~nm}$ and $230 \mathrm{~nm}$ (260/230) is used as a secondary measure of nucleic acid purity. The 260/230 values for pure nucleic acid are often higher than the respective $260 / 280$ values. A good-quality DNA sample should have an absorbance 260/280 ratio of $1.8-2.0$ and a 260/230 ratio of 2.0-2.2 [12]. The average absorbance at $260 / 280 \mathrm{~nm}$ for the samples obtained by this method was $1.94 \pm 0.09$ and the average absorbance at $260 / 230 \mathrm{~nm}$ was $2.23 \pm 0.2$.

Plasmids extracted with the described method were successfully used for transfection of HEK293T cells and lentivirus production.

Transfection of mammalian cell cultures is a very powerful tool in various biological fields. We used a basic protocol using the cationic polymer PEI. This method is suitable for different purposes and can be done with good efficiency in different stable cell lines. The efficiency of HEK293T transfection on the third day was more than 90\% (measured using a CytoFLEX flow cytometer (Beckman Coulter, Brea, CA, USA)).

The protocol for the production of lentiviral vectors is suitable for various lentiviral transfer plasmids with an insert size up to $15 \mathrm{~kb}$ [13].

Using this method for the production of lentiviruses, using the plasmids pMD2 (Addgene plasmid \#12259), PAX2 (Addgene plasmid \#12260) and pLenti-CMV-GFP Hygro (656-4) [8], we obtained viral titers up to $1.5 \times 10^{8} \mathrm{TU} / \mathrm{mL}$. Measurements of the calculation of the efficiency of transduction with lentivirus were carried out on a CytoFLEX flow cytometer (Beckman Coulter, Brea, CA, USA). As an example, we present a photo of HEK293T for three days during the virus production (Figure 2). Figure 2 compares two techniques: the bright field presents a number of cells infected with the virus 
and their morphological alterations, while GFP depicts the viral assembly. With the three days of growth, an increase in the GFP intensity is noticeable and so too the assembled viral particles.
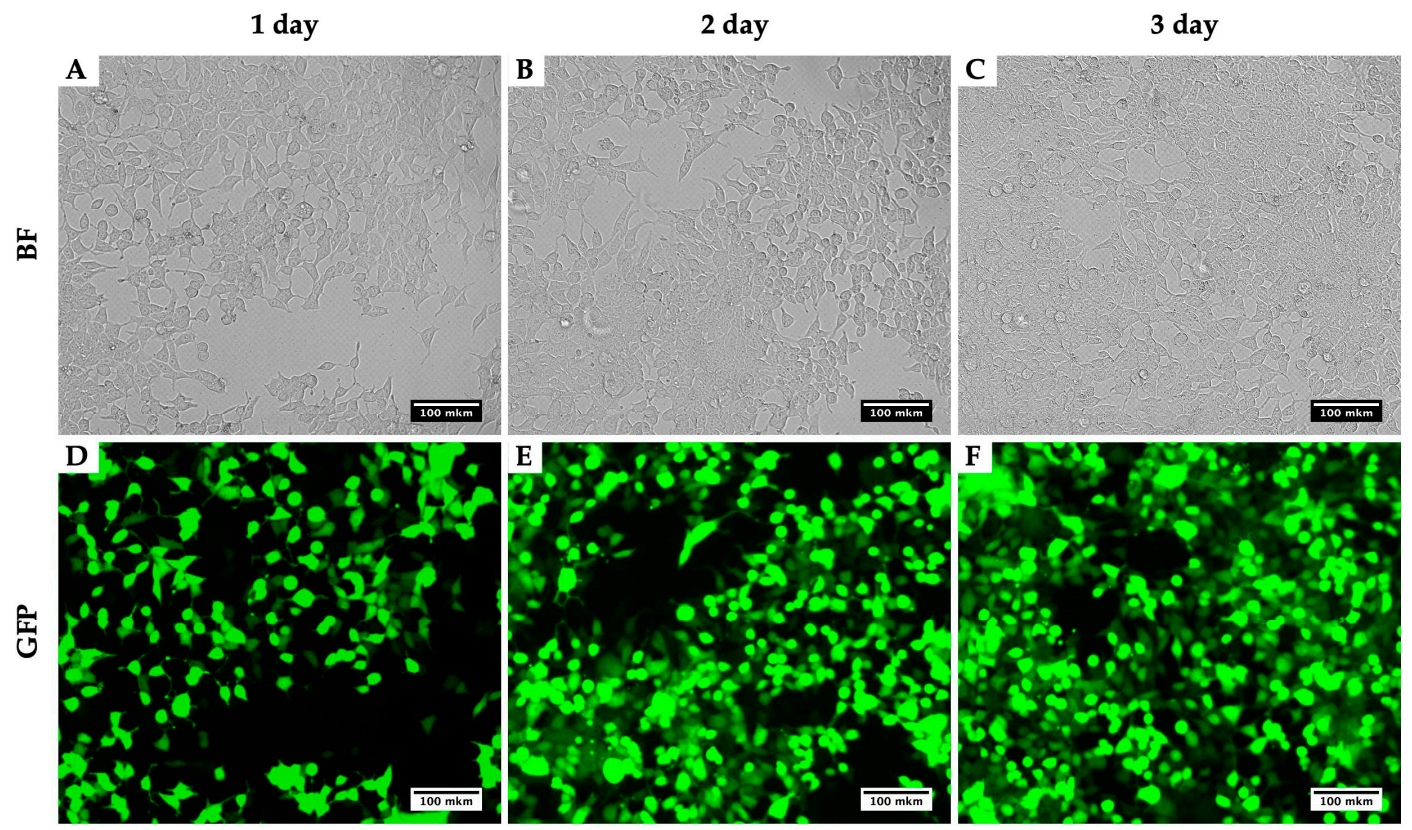

Figure 2. Dynamics of GFP signal accumulation in HEK293T within three days during the LV-CMV-EGFP Hygro (656-4) virus production. BF, brightfield; GFP, detection of green fluorescence. HEK293T cells $24 \mathrm{~h}(\mathbf{A}, \mathbf{D}), 48 \mathrm{~h}(\mathbf{B}, \mathbf{E})$ and $72 \mathrm{~h}(\mathbf{C}, \mathbf{F})$ after initial transfection with plasmids for LV-CMV-EGFP Hygro (656-4) production.

We describe the obtaining of LV-CMV-EGFP Hygro (656-4) that has a good transduction efficiency with both immortalized (more than $98 \%$ efficiency on the third day) and primary mammalian cell lines (60-80\% efficiency on the third day, depending on the cell type).

\section{Reagents Setup}

LB. $1 \%$ tryptone, $0.5 \%$ yeast extract, and $1 \% \mathrm{NaCl}$. To obtain a solid medium, add agar to a final concentration of $2 \%$. Add deionized water. Shake until the solutes are dissolved and autoclave for $30 \mathrm{~min}$. Store liquid medium at room temperature (or at $+4{ }^{\circ} \mathrm{C}$ ) and add the appropriate antibiotics before use. In the solid medium, add antibiotics after cooling the medium to $45-50{ }^{\circ} \mathrm{C}$ and pour into Petri dishes. Store at $4{ }^{\circ} \mathrm{C}$.

TBR. Deionized water up to $900 \mathrm{~mL}, 12 \mathrm{~g}$ tryptone, $24 \mathrm{~g}$ yeast extract, and $4 \mathrm{~mL}$ glycerol. Shake until the solutes are dissolved and autoclave for $30 \mathrm{~min}$. Add $100 \mathrm{~mL}$ of sterile solution of $0.17 \mathrm{M}$ $\mathrm{KH}_{2} \mathrm{PO}_{4}, 0.72 \mathrm{M} \mathrm{K}_{2} \mathrm{HPO}_{4}\left(2.3 \mathrm{~g}\right.$ of $\mathrm{K}_{2} \mathrm{HPO}_{4}$ and $12.5 \mathrm{~g}$ of $\mathrm{KH}_{2} \mathrm{PO}_{4}$ in $90 \mathrm{~mL}$ of $\mathrm{H}_{2} \mathrm{O}$; after the salts are dissolved, add $\mathrm{H}_{2} \mathrm{O}$ up to $100 \mathrm{~mL}$ ).

TEG. $50 \mathrm{mM}$ Glucose, $25 \mathrm{mM}$ Tris $\mathrm{HCl}(\mathrm{pH}=8.0)$, and $10 \mathrm{mM}$ EDTA $(\mathrm{pH}=8.0)$. Add deionized water. Autoclave for $30 \mathrm{~min}$. Can be stored at room temperature.

Lysis solution. $0.2 \mathrm{~N} \mathrm{NaOH}$ (freshly diluted from a $5 \mathrm{~N}$ stock) and $1 \%(\mathrm{w} / \mathrm{v}) \mathrm{SDS}$ (freshly diluted from a $10 \%$ stock). Store solution at room temperature.

10x TE buffer. $100 \mathrm{mM}$ Tris- $\mathrm{HCl}(\mathrm{pH}=8.0), 10 \mathrm{mM}$ EDTA. Sterilize solution by autoclaving for $30 \mathrm{~min}$. Store the buffer at room temperature.

Polyethylenimine. For the PEI $(1 \mathrm{mg} / \mathrm{mL})$ preparation, see the recommendations written by the manufacturer [14].

Author Contributions: Conceptualization, D.V.K. and J.I.K; validation, D.V.K., J.I.K., J.S.I. and A.A.R.; writingoriginal draft preparation, D.V.K.; writing—review and editing, D.V.K., J.I.K., J.S.I. and A.A.R.; visualization D.V.K. 
and J.I.K.; supervision, A.A.R.; methodology, D.V.K. and J.I.K.; funding acquisition, A.A.R. All authors have read and agreed to the published version of the manuscript.

Funding: The reported study was funded by a Russian Science Foundation grant № 20-14-00148 (Lentivirus production and cell cultures transfection) (D.V.K. and A.A.R.), the Russian Foundation of Basic Research 19-34-90153 (D.V.K.) and 19-34-90146 (J.I.K.), and by project 51140332 from the St. Petersburg State University (D.V.K. and A.A.R.).

Acknowledgments: The authors are grateful to Julia V. Sopova (Laboratory of Amyloid Biology, St. Petersburg State University) for valuable advice and comments while working on the protocol and Maria S. Rubel (SCAMT Intitute, ITMO University) for guidance and valuable comments in preparing the publication. We also acknowledge the St. Petersburg State University Resource Centers «Molecular and Cell Technologies», «CHROMAS» and «Biobank» for technical support.

Conflicts of Interest: The authors declare no conflict of interest.

\section{References}

1. Wurm, F.M. Production of recombinant protein therapeutics in cultivated mammalian cells. Nat. Biotechnol. 2004, 22, 1393-1398. [CrossRef] [PubMed]

2. Kim, T.K.; Eberwine, J.H. Mammalian cell transfection: The present and the future. Anal. Bioanal. Chem. 2010, 397, 3173-3178. [CrossRef] [PubMed]

3. Benskey, M.J.; Manfredsson, F.P. Lentivirus Production and Purification. Methods Mol. Biol. 2016, 1382, $107-114$. [CrossRef] [PubMed]

4. Longo, P.A.; Kavran, J.M.; Kim, M.S.; Leahy, D.J. Transient mammalian cell transfection with polyethylenimine (PEI). Meth. Enzymol. 2013, 529, 227-240. [CrossRef] [PubMed]

5. Sakuma, T.; Barry, M.A.; Ikeda, Y. Lentiviral vectors: Basic to translational. Biochem. J. 2012, 443, $603-618$. [CrossRef] [PubMed]

6. Jiang, W.; Hua, R.; Wei, M.; Li, C.; Qiu, Z.; Yang, X.; Zhang, C. An optimized method for high-titer lentivirus preparations without ultracentrifugation. Sci. Rep. 2015, 5, 13875. [CrossRef] [PubMed]

7. Inoue, H.; Nojima, H.; Okayama, H. High efficiency transformation of Escherichia coli with plasmids. Gene 1990, 96, 23-28. [CrossRef]

8. Campeau, E.; Ruhl, V.E.; Rodier, F.; Smith, C.L.; Rahmberg, B.L.; Fuss, J.O.; Campisi, J.; Yaswen, P.; Cooper, P.K.; Kaufman, P.D. A versatile viral system for expression and depletion of proteins in mammalian cells. PLoS ONE 2009, 4, e6529. [CrossRef] [PubMed]

9. Birnboim, H.C.; Doly, J. A rapid alkaline extraction procedure for screening recombinant plasmid DNA. Nucleic Acids Res. 1979, 7, 1513-1523. [CrossRef] [PubMed]

10. Birnboim, H.C. A rapid alkaline extraction method for the isolation of plasmid DNA. Methods Enzymol. 1983, 100, 243-255. [CrossRef] [PubMed]

11. Biosafety Considerations for Research with Lentiviral Vectors. Available online: https://osp.od.nih.gov/wpcontent/uploads/Lenti_Containment_Guidance.pdf (accessed on 14 October 2020).

12. Desjardins, P.; Conklin, D. NanoDrop Microvolume Quantitation of Nucleic Acids. JoVE 2010, 2565. [CrossRef] [PubMed]

13. Counsell, J.R.; Asgarian, Z.; Meng, J.; Ferrer, V.; Vink, C.A.; Howe, S.J.; Waddington, S.N.; Thrasher, A.J.; Muntoni, F.; Morgan, J.E.; et al. Lentiviral vectors can be used for full-length dystrophin gene therapy. Sci. Rep. 2017, 7, 79. [CrossRef] [PubMed]

14. Polysciences. Available online: https://www.polysciences.com/skin/frontend/default/polysciences/pdf/24765_ usage_guide.pdf (accessed on 28 August 2020).

Publisher's Note: MDPI stays neutral with regard to jurisdictional claims in published maps and institutional affiliations. 